Article

\title{
Land Politics under Market Socialism: The State, Land Policies, and Rural-Urban Land Conversion in China and Vietnam
}

\author{
Hoang Linh Nguyen ${ }^{1}{ }^{\mathbb{D}}$, Jin Duan ${ }^{1, *}$ and Guo Qin Zhang ${ }^{2}$ \\ 1 Department of Urban Planning, School of Architecture, Southeast University, Nanjing 210096, China; \\ hoanglinh2739@gmail.com \\ 2 Department of Architecture, Shanghai academy of fine arts, Shanghai University, Shanghai 200444, China; \\ guoqin9971@sina.com \\ * Correspondence: seduanjin@263.net; Tel.: +86-025-8379-4226
}

Received: 6 March 2018; Accepted: 15 April 2018; Published: 17 April 2018

\begin{abstract}
This paper undertakes a comparative analysis of rural-urban land conversion policies in China and Vietnam, and examines the ideology of the state in land policymaking under a market socialism environment. It argues that land policies in both countries include ambiguous boundaries, which allow the socialist state to legitimize its politico-administrative power in land management and retain strong intervention capacity in the land market. In addition to similarities, land policies in China and Vietnam show significant differences in terms of the ownership of rural land and related legislation on land expropriation and transactions. Together, these distinctions cause divergent impacts on the interests and motivations of multiple stakeholders in rural land conversion. It is further observed that the state in both countries is characterized by dynamic, complex, and self-coordinated institutional systems, in which multiple levels of government have different driving forces and strategies in land development. The internal structure of authority in rural-urban land conversion between the multiple levels of government is readjusted by the regulatory land control of the central government.
\end{abstract}

Keywords: China; land policy; state; land conversion; Vietnam; rural; urban

\section{Introduction}

It has been more than three decades since economic reform (The economic reform in China, known as "gaige kaifang", started in 1978. In Vietnam, this process, known as "Doi Moi", began in 1986. In both countries, it was an economic and political reform initiated with the introduction of policy change from a planned economy towards a "socialist-oriented market economy".) in China and Vietnam (hereafter $\mathrm{C} \& \mathrm{~V}$ ) marked a significant shift in both countries from a planned economy to market socialism. Marketization began with the relaxation of state governance over resources and economic and social activities. Land-use rights (hereafter LURs) in the urban sector subsequently became a kind of valuable commodity that could be transferred and exchanged on the land market. In parallel, decentralization in land management and fiscal reforms have also been implemented in both countries. Local governments with administrative authority over land that have benefited from land revenue have played an active role in local land development and the city construction process. With the emergence of the land market, land policies in both countries have experienced many reforms aiming to regulate market institutions and reconcile the internal structure of the state's authorities in land governance.

From the perspective of land politics, it has been recognized that the land regimes in C\&V retain some politico-administrative features inherited from their socialist roots [1-3]. McGee (2009) [4] has 
argued that the process of policy reform and production of space in C\&V is a "hybrid" institutional arrangement, because it combines socialist elements with the more recent market logic of capital circulation and accumulation. Indeed, contemporary land policies in $C \& V$ reflect features of transitional institutions in which the relation between multi-level government and the new market institution has not been clearly addressed. In recent years, a number of studies have sought to build understanding by analyzing the "growth coalition" of political elites in land development $[1,5,6]$, land financing and urban expansion in China [7,8], the commodification of land and urban space [9], and the conversion of farmland for non-agricultural uses $[2,10,11]$. The remaining questions are as follows: Are there convergences and divergences in the way in which the philosophies of market socialism have affected the state's ideology and land policymaking in these different contexts? What is the relation between the state and the market and between the multiple levels of government in current land policies, and how does it affect rural-urban land conversion? Despite the potential for a comparative study, researchers on $\mathrm{C} \& \mathrm{~V}$ have rarely looked at the wider neighborhood to find answers to these questions. Building on a critical review of collected data from legal documents, policy papers, international agency reports, research articles, and newspapers, this paper attempts to address these questions through a comparative analysis of contemporary land policies and rural-urban land conversion in $\mathrm{C} \& \mathrm{~V}$.

A comparison of land policies in $\mathrm{C} \& \mathrm{~V}$ is interesting for the following reasons. First, they are two transitionally socialist countries that have experienced similar processes related to globalization, marketization, and decentralization, since implementing economic reforms. Therefore, despite their historical and cultural differences, $C \& V$ share many common features in their contemporary administrative structure and land policies. Second, C\&V actively pursue economic growth and prioritize industrialization and modernization, which has led to an urban-centered development strategy in both countries. Third, the rapid urbanization in $C \& V$ has led to the expansion of cities and significant conversion of farmland for urban development in recent years.

However, the contemporary land system in Vietnam differs markedly in terms of land ownership structure from its neighbor. Vietnam has experienced agricultural de-collectivization since implementing economic reforms. Land ownership in Vietnam now lies with the "entire people", and it is governed by the state in either urban or rural sectors. China maintains a dual land ownership system - namely, collective land ownership for rural land and state-owned land in the urban sector. Therefore, a comparison of rural-urban land conversion is the best way to determine the convergence and divergence in current land policies between these two transitionally socialist countries.

This paper has three specific aims. The first is to examine the ideology and intention of the state in land policymaking under a market socialism environment in C\&V. Second, this paper aims to analyze the similarities and differences in contemporary land policies between the two countries and the resulting effects on the interest of stakeholders in rural-urban land development. The third aim is to explain the motivation of local elites in rural-urban land conversion, and the strategies used by the central government in $\mathrm{C} \& \mathrm{~V}$ to re-assert its regulatory control through policy instruments. The paper begins in the next section by reviewing the institutional changes in the context of each country.

\section{The Context}

Since their respective economic reforms, both countries have, on the one hand, gradually opened their markets to attract global capital and, on the other hand, promoted the pace of administrative reform through decentralization processes. Marketization in this regard involves a shift of state dominance in land development rights towards non-state sectors, and allows capital accumulation in land and in the built environment. In addition, state functions in both countries related to economic and land management were decentralized to subnational levels, and the authority of local governments in land development were extended. These gradual and uncertain reform processes in $\mathrm{C} \& \mathrm{~V}$ were based on an experimental and variable legacy system that, using Deng's metaphor, is "like a man who is groping for stones to cross the river" [4,12]. Indeed, the two socialist countries have adopted a prudent 
approach to marketization and decentralization, continually readjusting the state-market-civil society relations and the structure of authority between multiple levels of government through policy reforms.

Currently, land in C\&V remains publicly owned. After the economic reforms, the establishment of LURs and the related legislation system accelerated the process of commodifying the land and the built environment [13]. In both countries, land ownership and LURs are separated; only the latter are commoditized and allowed to be privatized and transferred between users with specific uses in the short term. Therefore, the urban land market in C\&V is a leasehold system of LURs. This system is thus fundamentally different from the full-fledged land market in Western countries, which is based on legal protection and the clear definition of property rights. The introduction of market institutions for land has changed the role of the public and private sectors in urban development. City governments gradually withdrew from their dominant position in space production and focused on their responsibility to create a better investment environment through planning tools and infrastructure improvement. On the other hand, the private sector in both countries is allowed to take part in the land transaction market because the land had been recognized as a special commodity. In China, the user rights of state-owned urban land have been officially determined as independent economic rights since the 1990s. In the same period, based on the introduction of the Law on Land in 1993, LURs can now be transferred, exchanged, mortgaged or given as a gift in Vietnam. These market-based reforms have created the legal foundation for the land transaction market; since then, land had become a valuable and marketable resource, leading to a process of capital accumulation in land and urban space in both countries.

In the rural sector, after the agricultural de-collectivization in the late 1980s, agricultural and homestead LURs in Vietnam were distributed to each farming household [14]. However, while homestead LURs can be transferred on the land market, transactions involving agricultural LURs in Vietnam are permitted only between farming land users, and they are strictly controlled by the state. In China, collective ownership of land is maintained in the rural sector, and land conversion by the state is the only legal way to transfer collective land into the urban sector. Many studies have observed the ambiguity of property rights for collectively owned land in China, which has affected rural-urban development [15-19]. This dual rural-urban system and the related land legislation have created an artificial segmentation between the urban and rural land markets in contemporary China.

Parallel with marketization, the decentralization process in $C \& V$ has shifted more authority over land governance downward to local governments. Following this trend, the land legacy system in the two countries has experienced many reforms to readjust the relation between the state and the newly emerging market institutions, as illustrated in Figure 1. In addition, land policy reforms are a tool used by the central state to restructure the authority over land management between multiple levels of government. Currently, land governance in $\mathrm{C} \& \mathrm{~V}$ is based on a hierarchical administrative system, where various levels of government are involved in land development, which they directly manage [15]. Many studies have shown the increasing power of local governments in land management owing to the decentralization process $[5,15,20]$. Accordingly, some scholars have observed a growth coalition between local governments and developers in both countries to push economic growth and urban expansion [8,11]. Further, scholars have also highlighted the "disobedience" of local governments to central policy, and their role in illegal land expropriation and transactions has contributed to the development of a "black land transaction market" in both countries [2,21,22]. Under these circumstances, the central governments in $C \& V$ have taken measures to regulate the land market and reassert control over land management through policy reforms, as we will analyze in more detail below through the case of rural-urban land conversion. 


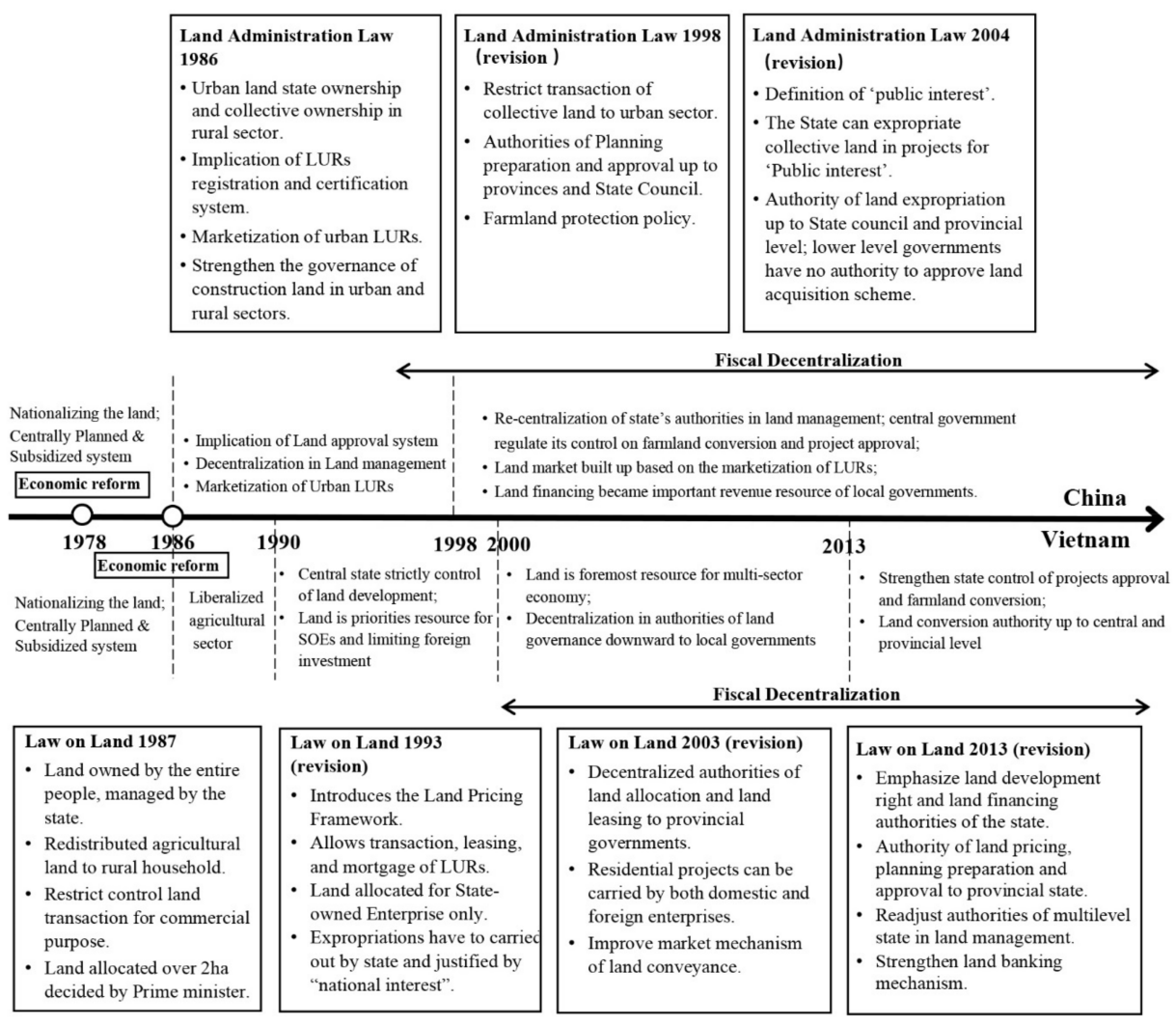

Figure 1. The land policy reform process in China and Vietnam. (Source: the authors).

Under the process of fiscal decentralization, the tax sharing policy established in both countries has clearly divided income and expenditure duties between the national and subnational levels of government. Provincial authorities have autonomy in determining the fiscal relationship (expenditure assignments and revenue sharing) with districts and communes within their jurisdiction. Although sublevels of government have authority in economic management, they lack their own source of revenue, and are not authorized to issue bonds [23]. In China, the tax sharing policy of 1998 readjusted the structure of the central-local revenue ratio, and dramatically expanded the central government's fiscal income [7]. By contrast, the local government's tax revenue ratio has been decreasing annually, reflecting a serious imbalance between local revenue and expenditure $[5,7,24]$. Local governments in Vietnam have faced the same problems. From 2000 to 2010, the proportion of local government revenue in Vietnam increased from $25 \%$ to $38 \%$, while local expenditure increased from $45 \%$ to $53 \%$ of total national spending [25]. In addition, the low efficiency of the current tax system in Vietnam has reduced local income, and funding to build infrastructure largely relies on intergovernmental transfer and foreign loans [23]. Therefore, the direct distribution of land revenue to local budgets has become a key revenue source for local development in $C \& V$, and multiple levels of government thus have a strong interest in becoming involved in land development to expand their local income and solve pressures on expenditure or to use land as a key factor to attract investment to their territory.

\section{Land Conversion Policies in the Market Socialism Environment}

\subsection{Ambiguous Boundary of State Intervention in Land Acquisition}

All member nations of the old socialist system devised land legislation based on the principles of state ownership or the people's ownership of all land, which allows the state to represent the "entire people" to expropriate land for public projects. In Vietnam, the current land conversion mechanism includes two major modes: compulsory land acquisition, which is based on the administrative decision 
of state bodies, and voluntary land conversion, which is based on the transaction of LURs between original land users and investors through negotiation. Compulsory land acquisition, which involves direct intervention by the state, has a profound impact on the livelihood of displaced land users. Therefore, there is an urgent need to clearly demarcate the boundary of the state's power with respect to the purpose and extension of compulsory land acquisition. However, the 2013 Land Law in Vietnam assigned local governments the authority to acquire land for purposes of socioeconomic development, in line with "national and public interest", which is broadly defined. Similarly, the "State-owned Land on the Housing Levy and Compensation Ordinance", published in 2011 in China, emphasizes that the government can expropriate land and other properties for the purpose of "public interest" without the consent of the property owner.

In the name of "national and public interests" (Compulsory land acquisition in Vietnam applied to the purpose of national defense or the development of the economy/society for the national and public interest requires illegal land use (for more detail, see Law on Land 2013: article No. 61-65).), governments in $C \& V$ are granted the power to convert land from the rural sector for urban development in the pursuit of economic growth and industrialization. In recent years, both countries have experienced rapid state-led urbanization processes, and a massive amount of rural land has been converted to meet the growing demand for urban expansion and industrial development $[20,26]$. In fact, from 2001 to 2009, it has been estimated that approximately one million hectares of farmland in Vietnam was converted for urban use [27]. In contrast, in China, widespread urban expansion caused a total loss of 3.3 million hectares of farmland during 2001 and 2013 [28].

Although the scope of "public interest" is limited by the law, the concept of "national interest" and "public interest" in C\&V does not restrict government expropriation decisions because of its ambiguity. This definition confuses economic growth and state-led urban development with the actual public interest of citizens. In this sense, the state-led construction of high-tech zones, industrial parks, and new towns (khu do thi moi) can also be considered within the scope of "public interest". Under the current land legislation system, the authority to acquire land based on land-use planning is granted to multiple levels of government, which can prepare and approve land-use planning and become involved in land acquisition within their territory. In theory, land-use planning should represent the "public interest" in urban development; however, both countries share some common issues in contemporary land-use planning. First, such planning reflects the ideology of state intervention in the land market, and has become an important tool for implementing state-led development projects. Second, land-use planning in $C \& V$ reflects the will of the government in local development rather than market demand, and becomes the legal foundation for attracting investment. Third, the current planning systems in both countries have a serious lack of public participation in the planning preparation and approval process. Hence, land-use planning in both countries is more of a state instrument to regulate land-use development than a means to fully represent the "public interest".

In theory, compulsory land acquisition in Vietnam is applied only to public security, welfare and foreign investment projects. Private and commercial projects funded by domestic investment are not subjected to compulsory land conversion; developers have to negotiate with the land users in LURs transactions based on the market mechanism. Nevertheless, in practice, local governments often become involved in land acquisition for many real estate projects under the name of land-use planning or new town development. Many examples can be found in Vietnam's cities. For instance, compulsory land acquisition was applied to the large-scale development of Eco-park, a new town in Hanoi, and Thu Thiem, a new district in Ho Chi Minh City [29,30]. In addition, market instruments, namely "land for infrastructure" and "build-transfer", are widely applied in many cities in Vietnam to the construction of public infrastructure. With these instruments, the state can treat land as a type of payment for the cost of building infrastructure and public facilities [1]. After the projects are finished, developers are allocated land by the government to invest in commercial projects or commodity housing. Certainly, such land is also within the scope of compulsory acquisition for "public-interest" projects. 
In China, no type of collective land can be directly transferred between rural land users and developers, which marks a significant difference in land conversion practices between the two countries. Because the land contract and management of collective LURs can only be internally circulated within the town and the collective's members (including arable land, collectively owned construction land, and homestead land) (The economic reform in China, known as "gaige kaifang", started in 1978. In Vietnam, this process, known as "Doi Moi", began in 1986. In both countries, it was an economic and political reform initiated with the introduction of policy change from a planned economy towards a "socialist-oriented market economy".), the only legal way to transfer land from the rural sector to the urban land market is through the land conversion process of the state, either for "public-interest" purposes or for commercial purposes. This is emphasized in article No. 43 of China's Land Administration Law: "any unit or individual that needs to use land for construction must apply for the use of state-owned land in accordance with the law". This regulation strengthens the 'monopoly power' of the government in rural land expropriation, and makes the state the only land supplier on the primary land market in China.

To strengthen the land supply capacity of the state, the land banking mechanism was introduced in the late 1990s, and rapidly became a major land expropriation model in China, while in Vietnam, this mechanism was introduced for the first time in 2003. Land banking strengthens the ability of governments to collect land for future urban development by purchasing sites and requiring land parcels based on land-use planning and the local government's economic development scheme. The separate land parcels are collected from land banking agencies, which carry out demolition, land levelling, and the construction of public facilities to meet the land transfer standards. Certainly, this mechanism can improve the municipal government's ability to regulate and control the land market, improve the efficiency of land development and increase local land revenue. However, in addition to these positive effects, under the current land regime, land banking also raises concerns about the dominant power of the state in land governance.

In Vietnam, the 2013 Law on Land allows provincial-level governments to establish "land banking and trading" agencies that are responsible for land conversion according to land-use planning. This mechanism has raised concerns about the dominant power of provincial-level governments in land development, especially since agricultural land in Vietnam can only be converted for urban use by the state (Compulsory land acquisition in Vietnam applied to the purpose of national defense or the development of the economy/society for the national and public interest requires illegal land use (for more detail, see Law on Land 2013: article No. 61-65).). In the case of China, as analyzed above, provincial governments have supreme authority in rural-urban land conversion. Similar to Vietnam, the implementation of the land banking system consolidated authority in rural-urban land conversion to create "monopolization" among Chinese local governments, where local governments are granted a series of responsibilities, including land-use planning preparation, compulsory land acquisition for development and land pricing. Hence, the governments in $C \& V$ play the role of both "the player and the referee" in the land development process, and their dominant power is legitimized by the law. In both countries, the boundary between state intervention and the market mechanism in rural land acquisition policies has not been clearly defined, which raises concerns regarding inequality in land development.

\subsection{Dual Track of Land Pricing in Land Compensation}

In Vietnam, land pricing is a powerful tool used by the state to regulate the land market. Since the early 1990s, the land-price framework (hereafter, LPF) has been used by the state as an instrument for all land-related valuations in the country, including establishing the compensation plan, allocating and leasing land, and calculating tax revenue [31]. Truong and Perera (2011) argued that this land pricing mechanism was intentionally designed by the state to attract more investment and control the accessibility of land to developers [32]. In 2003, the Law on Land officially granted provincial governments the authority to issue the LPF. The official land price in each province is annually adjusted 
to match the changing land value on the market. However, some recent studies have found that the official land price has failed to reflect the prevailing value of land. Indeed, the state-proposed rates for land appear to be 30-70\% lower than the estimated market value [27,32]. This dual track of land pricing in Vietnam has been shaped by the state's fixed land price and the prevailing price on the land transaction market.

In Vietnam, the compensation rate for compulsory land acquisition by the state is determined based on the LPF. Under this land pricing system, the cost of land compensation is minimized, which increases the investment profits for the parties of interest. Such profits are generated by the value gap between the dual track of land prices, which is determined by the administrative framework, and the market land price. In this way, developers capture substantial benefits from land value increases through development, while the profits flow to the state's budget in the form of rental fees and related land taxes. Scholars in Vietnam have widely observed unequal benefit sharing between stakeholders in rural land conversion, where land-losing farmers tend to benefit the least $[33,34]$. Therefore, the inequality of interests between the multiple stakeholders in land conversion has created conflicts in the stage of land compensation, which has led to delays in construction and harmed the interests of investors, with effects carrying down to the people and the local economy.

In China, the dual-track land tenure system and the limitations of property rights in the rural sector have widened the gap in land prices between the urban and rural sectors. Because rural LURs can only be internally circulated within the township's organization and the collective's members, collective land is restricted to transfer in the secondary land market (Article 63 of the Land Administration Law 2004 stipulates as follows: no right to the use of land owned by peasant collectives may be assigned, transferred, or leased for non-agricultural construction, with the exception of enterprises that have lawfully obtained land for construction in conformity with the overall plan for land utilization but have to transfer, according to law, their land-use right because of bankruptcy or merger, or for other reasons.). These regulations strengthen the state's control over access to collective land, and greatly weaken the property rights of rural land users and artificially keep the value of collective land lower than its market value.

As in Vietnam, current legislation on rural land compensation, which was established by the state, also purposely reduces the cost of land expropriation in China. Article No. 47 of the Land Administration Law states that "the value of compensation for cultivated land according to the original purpose of the land being expropriated and the total land compensation and resettlement subsidies shall not exceed 30 times the average annual output value of the expropriated land calculated on the basis of three years preceding such expropriation". This law also stipulates that compensation for other types of collective land, such as construction land and homestead land, should refer to the rates of compensation and resettlement subsidies for the expropriation of cultivated land. Under these mechanisms, the collective and its members receive only a fixed price in compensation that is decided by the administrative track, which is based on the agricultural productivity of the land without considering the market value. This artificially low compensation price has failed to maintain the living standard of affected farmers [5,35]. Conversely, this dual track of land pricing allows the government to expropriate collective land with low compensation costs, and then gain substantial profits from land value increases achieved through land conveyance. This process supports the observation of Lin that the state uses it authority to foster the land market and incentivizes local governments to pursue land finance and local economic growth [2].

\subsection{Land Conveyance System and Rural-Urban Land Transactions}

The unique land ownership system in China has created a dual land market system between the urban and rural sectors. As analyzed above, the only legal way to transfer collective land to the urban land market is through conversion by the state (Figure 2). The authority over land-use planning and the establishment of the land banking mechanism have created a monopoly position for the state in land supply for urban development. After land expropriation, the government reassigns the LURs 
to new land users or developers through land conveyance or the administrative allocation of land (tudi huabo) ("Tudi huabo": The administrative land allocation method is used to grant LURs to state or nonprofit users without any fees in China.). Land conveyance is a leasehold system whereby land parcels are conveyed to developers for a fixed term and fixed function through tender, auction, quotation, and negotiation modes (Land Administration Law 2004). This land leasehold system is based on the principles of market operation, in which developers must compete in land prices for state land allocation. The current land legislation in China combines the administrative power of the state with new market instruments, allowing the government to monopolize the land supply and maximize its income through the land conveyance system [2,5].

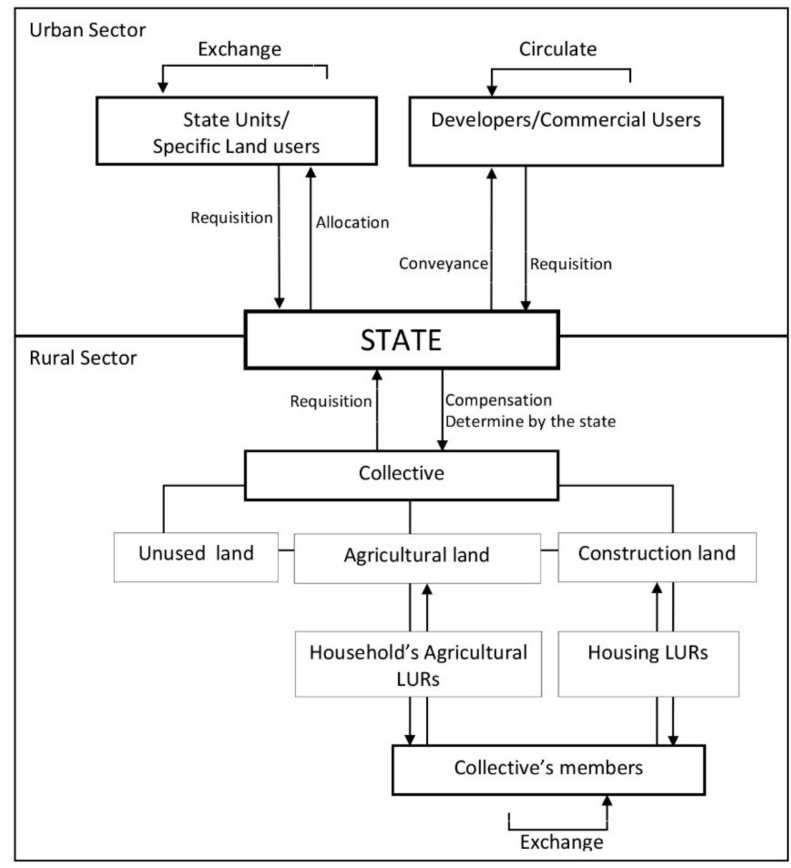

Figure 2. Framework of rural-urban land system in China (Source: the authors).

As in China, the land leasehold system in Vietnam includes a land conveyance method (auction, bidding, and negotiation modes) and an administrative land allocation method (allocate land without leasing fee) (Article 33 of the Law on Land 2013 in Vietnam stipulates that the state can allocate land to specific users without the collection of land-use fees.), which are applied only to specific projects. Land leasing through bidding and auction is based on market principles and requires a publicized and transparent assessment process, which tends to reduce the risk of corruption and help maximize the state's income from leasing land. By contrast, negotiation in land leasing between the government and investors can lead to mass corruption, because it grants the government the right to select investors through personal contacts and bribes, rather than based on quality and affordability [27]. However, current land legislation in Vietnam creates ambiguity, and there are internal conflicts in the regulations related to land conveyance. For instance, the 2013 Law on Land allowed negotiated conveyances to be applied only to public amenities, affordable housing projects, and in some specific circumstances (article No. 118). Nonetheless, article No. 110 in the same law allows local governments to apply negotiated conveyances to some projects "for production and business purposes in sectors or geographical areas that are given investment preferences", except for investment projects in commodity housing. This ambiguous regulation allows local governments to appeal to developers through "under-the-table" land transactions, and to use land as an important resource to attract investment to their jurisdiction, especially for industrial and economic development. This type of ambiguous regulation can also be found in China, where local governments continuously allow land leasing to industries through 
negotiation. $\mathrm{Wu}(1999)$ argued that the negotiation of land allocation grants local governments the authority to manipulate land prices to appeal to developers [36]. In contrast, Jiang $\mathrm{Xu}$ argued that this could be understood as a state strategy to sustain the competitiveness of China's manufactured products in the global market [9].

The major distinction in land transaction policies between $C \& V$ concerns the right to transfer land between land users and investors from the rural to urban land market (Figures 2 and 3). In Vietnam, agricultural LURs can only be internally circulated within farmer households and agricultural organizations (Article 190 of Law on Land 2013 stipulates as follows: agricultural LURs in Vietnam can be transferred/inherited/granted only between farming households/individuals in one commune/township.). However, the LURs of homestead land can be legally transferred between land users and developers from rural to urban sectors under the mechanism of negotiation. In comparison with that in China, this transaction mechanism for homestead land in Vietnam has proved to be advantageous in some respects. First, this mechanism prevents state monopoly in rural-urban land supply. Second, the transaction mechanism ensures the rights of participation and negotiation for land users in the land development process; hence, it efficiently protects the interest of the affected people in land development. Third, the legitimization of transaction rights regarding homestead land has positively improved the development of the formal land market in Vietnam and reduced illegal land transactions between rural and urban land users. However, current land legislation still restricts transactions shifting agricultural land to the urban sector. In this sense, the government in Vietnam maintains its monopoly position in agricultural land conversion. In fact, a large amount of agricultural land has been converted to non-agricultural use by the administrative decisions of multiple levels of government in recent years [11].

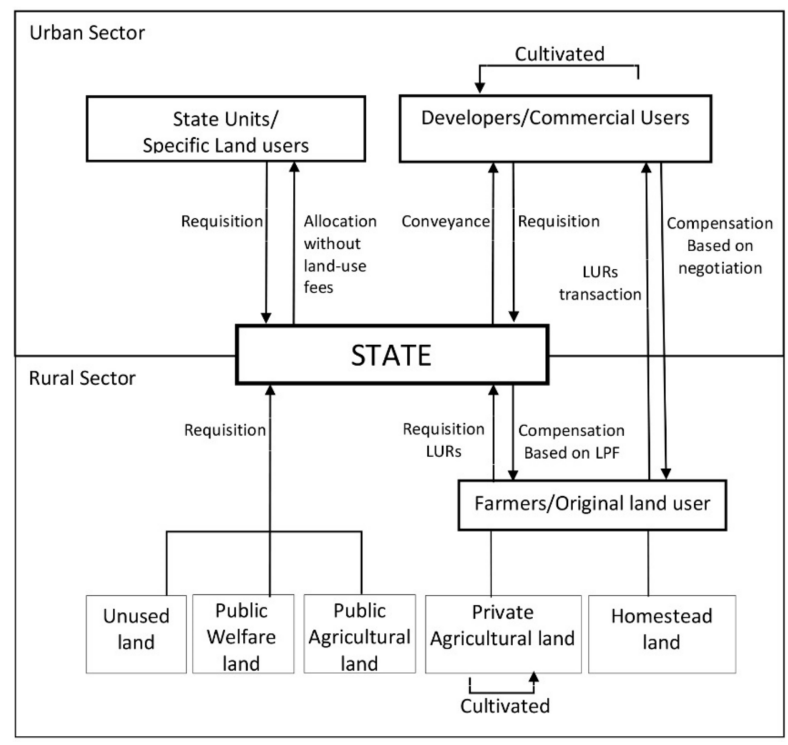

Figure 3. Framework of rural-urban land system in Vietnam (Source: the authors).

\section{Land Politics in Rural-Urban Land Conversion}

\subsection{Local Elites' Motivation}

As described above, the imbalance between local revenue and expenditure, as a negative aspect of fiscal decentralization, has increased financial pressure on local governments in C\&V. Currently, local governments in both countries lack their own revenue sources; rather, they heavily rely on tax revenue sharing with the central government as a form of intergovernmental transfer [23]. The current tax sharing policy in $\mathrm{C} \& \mathrm{~V}$ allocates a large proportion of land-related taxes and fees to local budgets (see Table 1). In this sense, land financing has become an important fiscal resource for local development. 
However, McGee (2009) argued that pressure from fiscal decentralization and competition among cities has had a far more dramatic impact on the urbanization process in China than on that in Vietnam [4]. In cities in which the local budget mainly relies on land revenue, the local government is more aggressive in exploiting land to generate revenue to support public spending [5,7]. Some studies have revealed that local governments in China have been performing like entrepreneurs, increasingly serving their own interest and maximizing their benefits [24,37]. As the agent of the state in land development, local governments are empowered to extensively convert collectively owned land and push the expansion of urban land to support local growth, which is called "land-centered" urbanization in China [7,28]. In Vietnam, since the beginning of fiscal decentralization, land-related revenue that is distributed to multiple levels of local government (provincial, municipal, and commune/district) has also become an important pillar of local budgets.

In his study, Tran Anh Tuan (2013) revealed that a large proportion of cities' fiscal income is generated from land revenue [38]. For instance, 30\% of local revenue in Ho Chi Minh City in 2010 was collected from land. In sum, local governments in C\&V have performed as "privileged market actors" in rural-urban land conversion; they are empowered as administrative authorities in converting rural land for urban growth, allowing them to directly benefit from this process. In this sense, local governments can no longer be seen as "impartial adjudicators" who are in charge of balancing the interests of other stakeholders; rather, they have transformed into "self-interested strategic players" that pursue local economic growth and political goals.

In China, under the contemporary land system, local governments can expropriate collective land with a low compensation rate, and then gain a substantial profit from land value increases after the conversion to urban land. Land conveyance (including tender, auction, and quotation) is the only step where following market operations helps maximize the local government's revenue in the land conversion process. The current legislation on collective land expropriation has created a monopoly position for the state in the primary land market and helped transfer "the hidden fortune" of land value, which previously belonged to the rural collectives and their members, to the urban sector. These policies are embedded in the "hybrid" characteristics of market socialism, where the compensation rate and expropriation are regulated by administrative decisions, but the profits of land conversion are collected in a market system.

In addition, the current dual-track land system in China also maintains lower prices for collective land and supports local authorities in using land as a strategic channel to attract investment to their jurisdiction. Xu et al. (2009) revealed local governments' strategies to manipulate land prices and allocation policies to create a favorable economic environment for industrial sectors and to enlarge their own income [9]. In this system, the government tends to allocate land to industries by negotiation, which, on the one hand, reduces the cost and risks of investors and, on the other hand, sustains local competitiveness. In contrast, the tender, auction, and quotation methods are widely applied to commercial projects, commodity housing, and other real estate development, to maximize revenue for the local budget [5]. 
Table 1. Land revenue sharing between central-local governments in China and Vietnam. (Source: the authors).

\begin{tabular}{|c|c|c|c|c|}
\hline & \multicolumn{2}{|c|}{ China } & \multicolumn{2}{|c|}{ Vietnam } \\
\hline & Tax Income & Non-Tax Income & Tax Income & Non-Tax Income \\
\hline Central-Local Budget & $\begin{array}{ll}- & \text { Enterprise income tax } \\
- & \text { Individual income tax } \\
\text { - } & \text { City maintenance and } \\
& \text { construction tax }\end{array}$ & $\begin{array}{ll}\text { - } & \text { Education } \\
\text { supplementary tax } \\
\text { - } & \text { New construction land } \\
\text { - } & \text { Sompensation fee } \\
& \text { Site use fees for } \\
& \text { foreign enterprises }\end{array}$ & $\begin{array}{ll}\text { - } & \text { Enterprise income tax } \\
\text { - } & \text { Individual income tax }\end{array}$ & \\
\hline Local Budget & $\begin{array}{ll}\text { - } & \text { Business tax } \\
\text { - } & \text { Urban land used tax } \\
\text { - } & \text { Increment tax on } \\
\text { - } & \text { land value } \\
\text { - } & \text { Deed tax } \\
\text { - } & \text { Stamp tax }\end{array}$ & $\begin{array}{ll}\text { - } & \text { The new vegetable field } \\
\text { - } & \text { Saleselopment fund } \\
\text { - } & \text { state-owned property } \\
\text { - } & \text { Land reclamation fee } \\
\text { - } & \text { Vacant land fees } \\
\text { - } & \text { Land acquisition } \\
\text { - } & \text { management fee } \\
\text { Registration fees }\end{array}$ & $\begin{array}{ll}\text { - } & \text { Business tax } \\
\text { - } & \text { Non-agricultural land } \\
\text { - } & \text { Farmland occupation tax } \\
\text { - } & \text { Contract tax }\end{array}$ & $\begin{array}{ll}\text { - } & \text { Sales of } \\
\text { - } & \text { state-owned property } \\
\text { - } & \text { Land rent } \\
\text { - } & \text { Land-use charge } \\
& \text { Registration fees }\end{array}$ \\
\hline
\end{tabular}


As in China, the local governments in Vietnam also treat land as an important resource for boosting local economic growth, attracting investment, and generating local revenue. Under the current LURs system, the local government, as the de facto landowner, has been granted dominant authority regarding land in both the rural and urban sectors. The authorities on land pricing allow provincial governments to manipulate land value in their jurisdictions, and to use a low-land pricing policy as a key factor to attract more investment. Under the dual land pricing system, enormous profit from land rent is created by the gap between the administrative land price and the value of land from the market after re-development. These profits are distributed to local governments in the form of land rent, taxes, and fees, while developers pocket a large share of the land value increase through the development process. In this process, the conversion of agricultural land, which has the lowest land value in the LPF, to urban land, will maximize the profit of local elites and minimize the cost of development. This situation explains the high interest of local elites in agricultural land conversion and their land rent-seeking activities in Vietnam in recent years.

The transaction mechanism for rural homestead land in Vietnam has avoided the monopolization of the state in land supply for urban development, which marks a major difference in rural-urban land transactions from China. In this mechanism, homestead land users and developers can negotiate "face-to-face" about compensation and conditions of displacement in private/commercial projects. This mechanism strongly protects the property rights of land users by increasing the participation and bargaining power of the displaced [39]. The disadvantageous side of this mechanism is that disagreement between land users and developers can cause delays in projects, which leads to waste of land, and has a negative impact on local development [31]. In addition, this mechanism normally does not work in large-scale real estate projects, such as new town development, which must include both homestead land and agricultural land. Nonetheless, we can list many cases of new town development in Vietnam that can be considered real estate development, such as the projects of Eco-park, a new town in Hanoi; Thuy Duong, a new town in Hue; and Thu Thiem, a district in Ho Chi Minh City $[11,29,30]$. Under current policies, local governments remain involved in compulsory land acquisition for the construction of new towns or projects that are listed in "priority economic development categories" (Law on Land 2013). Hence, developers, as profit seekers, can rightfully rely on the support of local governments, which have decisive power in land acquisition. Our assessment is that rural-urban land conversion policies in Vietnam are more flexible than those in China in establishing multi-track land supply, but the state remains dominant in agricultural land acquisition for urban development. This ambiguity and incompleteness of current land policies in Vietnam therefore still opens the door for a growth coalition between local authorities and developers.

\subsection{Regulatory Land Control by the Central Government}

During recent decades, Vietnam and China have experienced rapid urbanization processes. The flows of capital into industrial and urban development in the peri-urban areas have become the major driving forces behind labor migration and urban expansion. The demand for new urban space focused on urban fringe areas closely linked to existing urban centers takes advantage of the cheaper land prices and room for expansion. In these decades, the publicly and privately led construction of new towns, industrial zones and residential projects, and land-speculation activities at local levels, have created an overheated real estate market in C\&V. A massive amount of agricultural land has been converted to urban use, raising concerns about national food insecurity, social instability, and unsustainable environmental problems. Under these circumstances, the central governments of both countries should reassert their regulatory position by introducing a number of measures to improve the efficiency of the land market, protect farmland, and control urban expansion. Policy readjustment and land reform remain the main instruments used by the party-led central government to exert control over local elites and remain relevant in land development.

In the early 1980s, China established a mechanism, namely, the "Annual quota allocation system", to control the dramatic loss of agricultural land at local levels and force local authorities to rationalize 
land use. With this mechanism, the central government developed overall plans for land utilization and set up a total amount of agricultural land that can be converted for non-agricultural uses each year. Subsequently, authority regarding this quota was decentralized downward to various subnational levels. The 1990s marked a shift in the approach towards farmland protection in China. The central government changed its strategy by establishing a "bottom-line" of basic farmland protection at the national level and in each region, as this was considered necessary for agricultural production. The mechanisms, namely, "Protected farmland regions" in 1991 and "Regulations for the protection of basic farmland" in 1994, emphasized the responsibility for preserving basic farmland at local levels, and aimed at controlling the conversion of agricultural land to development projects. Subsequently, much legislation related to farmland protection was established in the first half of the 1990s; however, the "Farmland protection policy" in the Land Management Law of 1998 had the strongest influence. This law coercively requires provincial governments to classify at least $80 \%$ of cultivated land in their jurisdiction as "basic farmland" and strictly preserves it to ensure demand for local agricultural production (Land Management Law 1998, Article 34). Thus, article 33 of the same law also requires provinces to adopt measures to ensure that the total amount of farmland within their administrative region is not reduced; otherwise, the provincial government takes responsibility for restoring the same amount of farmland within its jurisdiction. Meanwhile, article 45 stipulates that any projects requiring cover land exceeding 70 hectares or cultivated land exceeding 35 hectares must be approved by the State Council. Since 2000, the central government in China has published many regulations to implement and embody this policy. Although policy on farmland protection has become an important national macro-control instrument in China, it has been criticized by scholars because of its limitations. Cang et al. (2006) argued that this coercive policy has been generated by the inexorable ideology of rigid control by the political central government [40]. A number of other scholars have also criticized the inflexible nature of this mechanism, as it requires the same quota of farmland to be preserved in all regions and at all administrative levels, but neglects the diversity and actual development demand between different regions and cities [40,41].

Unlike that in China, the central government in Vietnam does not use a strong policy on farmland protection as a measure to control local growth. Instead, it adjusts the extent of authority in project approval at subnational levels to control the power of local government in rural-urban land conversion. Because authority regarding land governance in $C \& V$ is based on a "hierarchical review and approval system" that allows various administrative levels to review and approve requests for land conversion [2,9], in the early 1990s, authority over agricultural land acquisition and allocation for development projects in Vietnam was strongly centralized, and any change in land use had to be approved by the Ministry of Natural Resources and Environment (Law on Land 1993, Article 23). Provincial governments could convert land only for projects up to 1 ha for agricultural land and up to 2 ha for mountain land (Law on Land 1987). The establishment of the Law on Land in 2003 marked the beginning of the decentralization of land management in Vietnam (see Figure 1). Under this law, local officials at the district/commune level were granted authority over land acquisition and allocation for households/individuals, while townships were in charge of managing public land use and public agricultural land in their territory. Subsequent decentralizing regulations in 2006 and 2009 extended the authority of provincial governments to approve development projects in their territory (Decree 108/2006/ND-CP) and allowed them to convert land for new town development for areas up to 200 ha (Decree 12/2009/ND-CP). Consequently, rapid state-led urbanization led to a dramatic loss of agricultural land, which was converted for urban expansion and industrial development. According to a report by an international organization, approximately one million hectares of agricultural land in Vietnam were converted for non-agricultural use from 2000 to 2009 (Embassy of Denmark et al., 2011). Confronting this problem, the central government restructured land management authority at the subprovincial levels in the Law on Land of 2013. Authority regarding agricultural land acquisition and conversion was rescaled upward to the provincial level. According to article 59 of this law, commune governments now only have the right to convert agricultural land to commercial use for 
areas of a maximum of 0.5 hectare, while township officials can now only allocate agricultural land for public purposes, and the right to acquire public land in towns has been returned to provincial governments. Further, the central government also tightened control of land allocation at the provincial level. Provinces are now only allowed to convert land for development projects between 20 ha and 100 ha; projects that require the conversion of more than 100 ha of land must be approved by the prime minister (Decree 11/2013/ND-CP). In addition, the central government introduced stronger regulation to preserve specific land uses; provinces are allowed to approve projects that require less than 10 hectares of cultivated land or 20 hectares of forest land (Decree 35/2015/ND-CP).

Parallel with the above measures, the central government in both countries also attempted to strengthen its supervisory control in the hierarchical land management system. In both countries, the Ministry of Natural Resources and Environment is charged with a full range of land governance functions, such as guiding land-use planning preparation, implementing farmland protection policy, and supervising land development activities at local levels. Meanwhile, a land department system was implemented for all levels of subnational government, from provinces to townships, to strengthen the hierarchical linkage of land governance and the supervisory capacity of the state. Although the land departments at subprovincial levels are directly managed by the provincial government, they are also supervised by the Ministry of Natural Resources and Environment, and they act as the "eyes and the ears" of the central government in local land management.

Observing the measures taken by the central government, we can conclude that the central government in $C \& V$ has played a leading role in adjusting land policy. The central government, on the one hand, has granted autonomy to local governments to incentivize local economic growth and, on the other hand, has used measures to reassert regulatory control and force local governments to rationalize local land development.

\section{Conclusions: Convergence and Divergence of Land Politics in C\&V}

This paper examines the commonalities and differences in contemporary rural-urban land conversion policies and the effect of such policies on rural-urban land development in both C\&V. With this focus, this paper provides a comparative perspective on two socialist countries, and it may better explain the ideology of transitional states in land policymaking under the orientation of market socialism. Based on the comparative analysis of land politics and rural-urban land conversion policies in $\mathrm{C} \& \mathrm{~V}$, we can offer the following remarks:

First, land politics under market socialism are reflected in the existing dual-track institutional system, which maintains the powerful authority of the state in land governance and includes an emerging market institution. The current land policies in $C \& V$ show converging features of combined market and socialist principles, which create ambiguous boundaries between market-based mechanisms and the intervention capacity of multiple levels of government. In this regard, the socialist state can legitimize its position as a market enabler and administrator through its authority over land management and policymaking. The dual-track land system in China has been based on the state's ideology: a desire to control the flow of capital and population between urban and rural sectors, and to open up the land market to attract investment in industry and real estate by maintaining the competitive advantage of low land prices. In Vietnam, because of the LPF, land banking system and ambiguous role of the state in land acquisition, land has also become an important channel for attracting investment and reducing the cost of urban development. This paper offers evidence showing that land policies in $C \& V$ are purposely devised and conditioned to maintain the power of the state in land development.

Second, local governments in $\mathrm{C} \& \mathrm{~V}$ have a strong administrative authority and benefit from land rent; thus, they are highly interested in pursuing local economic growth through state-led land development. Incentive policies on land have become the strategy used by local governments to involve capital flows from the private sector to realize their development schemes. From the perspective of developers, under the current land-use regime, they directly benefit from investment in real estate or 
industries in the peri-urban area. Developers, on the one hand, play an active role in profit-seeking in the rural-urban land conversion process; on the other hand, they also contribute to the urbanization process by providing infrastructure, public amenities, and housing. In both countries, local growth coalitions have emerged between state agencies and developers, who form alliances to convert land from rural to urban uses and to maximize the benefit from land value increases. The main difference between $C \& V$, we argue, lies in China's dual-track system of land ownership and its related legislation, which strengthens local governments' monopoly position in the primary land market and induces local government agents in China to become more active in rural-urban land conversion to achieve economic growth and create land revenue. In Vietnam, although current land policies also maintain the capacity of state intervention in land development, they are more flexible than those in China with respect to the land transaction mechanisms that are applied to "non-public interest" projects. On the one hand, this mechanism clearly delineates the boundary of administrative intervention by the state and LURs transactions through the market-based mechanism in private and commercial projects. On the other hand, it enables multiple tracks of land supply for urban development; thus, the state cannot monopolize the land supply in Vietnam. In addition, this mechanism effectively protects the legitimate rights of participation and negotiation for displaced land users in the land development process, and ensures better compensation and benefit sharing for them.

Third, land politics in C\&V embody the ideology of the transitionally socialist state. Both countries have taken gradual approaches to market reform, and state dominance exists in parallel with market institutions. In both countries, land policymaking and reform are dynamic processes used to adjust the relations between the state and the market, and between the various levels of government in the context of marketization and decentralization. As Lin and Ho (2005) suggested for China, it is important to recognize that the socialist state is a complex, heterogeneous, and internally-conflicting system, where various levels of government have different motivations and strategies regarding land development [2]. Despite marketization and decentralization, the policymaking and economies in C\&V remain under the control of the party-led central government, which has allowed the central government in both countries to reassert its regulatory position in land management and reconciliate the internal power relations of multiple levels of government through land policy reform. As analyzed above, the central government in China regulates rural-urban land conversion at the local level through three policy instruments: controlling the land supply at the local level, strengthening the hierarchical system of land management at various state levels, and establishing the farmland protection policy. In Vietnam, former policies are also applied to readjust the internal power relations of the state, yet the farmland protection policy has not been established as an instrument of national macro control. There is strong evidence that the similarities in land management and policy reform in $C \& V$ have far exceeded the variations. However, our assessment suggests that compared with that in Vietnam, the state in China has been able to impose much stronger intervention in the rural-urban land market by, for instance, maintaining a dual-track land system and enforcing farmland protection policy at the provincial level. This difference reflects the divergence of the two transitionally socialist countries in land policymaking. While China has maintained its position of state dominance by maintaining artificial segmentation between the urban and rural land markets, Vietnam, in its land policy system, has adopted a more flexible approach towards market reform and the reconciliation of land management authority.

Acknowledgments: The authors would like to thank Andrew Wells-Dang for his helpful comments on an earlier draft. Thanks also to Katerina Rudenko and Dang Quang Minh for their kind help in improving the English of this text.

Author Contributions: Hoang Linh Nguyen and Jin Duan developed the original idea of the study, Guo Qin Zhang was responsible for data and information collection. Hoang Linh Nguyen wrote the main framework, the analysis section and conclusion of the paper. Jin Duan and Guo Qin Zhang wrote the abstract, the literature review and contributed to the data collection.

Conflicts of Interest: The authors declare no conflict of interest. 


\section{References}

1. Labbé, D.; Musil, C. Periurban land redevelopment in Vietnam under market socialism. Urban Stud. 2014, 51, 1146-1161. [CrossRef]

2. Lin, G.; Ho, C.S.; Samuel, P.S. The state, land system, and land development process in contemporary China. Ann. Assoc. Am. Geogr. 2005, 95, 411-436. [CrossRef]

3. Yang, Y.C.; Zhang, D.L.; Meng, Q.M.; McCarn, C. Urban residential land use reconstruction under dual-track mechanism of market socialism in China: A case study of Chengdu. Sustainability 2015, 7, 16849-16865. [CrossRef]

4. McGee, T.G. Interrogating the production of urban space in China and Vietnam under market socialism. Asia Pac. Viewp. 2009, 50, 228-246. [CrossRef]

5. Zhang, Y.F.; Duan, J. Why is the Urban Development Land out of Control: An Analysis from the Perspective of the Land System. Mod. Urban Res. 2013, 9, 22-26.

6. Zhu, J.M. Local growth coalition: The context and implications of China's gradualist urban land reforms. Int. J. Urban Reg. 1999, 23, 534-548. [CrossRef]

7. Lin, Y.; Wu, A.M. Urbanization, land development, and land financing: Evidence from Chinese cities. J. Urban Aff. 2014, 36, 354-368.

8. Lichtenberg, E.; Ding, C. Local officials as land developers: Urban spatial expansion in China. J. Urban Econ. 2009, 66, 57-64. [CrossRef]

9. Xu, J.; Yeh, A.G.O.; Wu, F. Land commodification: New land development and politics in China since the late 1990s. Int. J. Urban Reg. 2009, 33, 890-913. [CrossRef]

10. Ho, S.P.S.; Lin, G.C.S. Emerging land markets in rural and urban China: Policies and practices. China Quart. 2003, 175, 681-707. [CrossRef]

11. Phuc, N.Q.; van Westen, A.C.M.; Zoomers, A. Agricultural land for urban development: The process of land conversion in Central Viet Nam. Habitat Int. 2014, 41, 1-7. [CrossRef]

12. Tao, R.; Xu, Z. Groping for stones to cross the river versus coordinated policy reforms: The case of two reforms in China. J. Policy Reform 2006, 9, 177-201. [CrossRef]

13. Nguyen, Q.; Kammeier, H.D. Changes in the political economy of Vietnam and their impacts on the built environment of Hanoi. Cities 2002, 19, 373-388.

14. Do, Q.T.; Iyer, L. Land Right and Economic Development: Evidence from Vietnam; World Bank: Washington, DC, USA, 2003.

15. Zhu, J.M. Urban development under ambiguous property rights: A case of China's transition economy. Int. J. Urban Reg. 2002, 26, 41-57. [CrossRef]

16. Xu, J.; Yeh, A.G.O. Decoding urban land governance: State reconstruction in contemporary Chinese cities. Urban Stud. 2009, 46, 559-581.

17. Ho, S.P.S. Who owns China's land? Property rights and deliberate institutional ambiguity. China Q. 2001, 166, 394-421. [CrossRef]

18. Ho, S.P.S. Institutions in Transition: Land Ownership, Property Rights and Social Conflict in China; Oxford University Press: Oxford, UK, 2005.

19. Chen, J.; Yang, S.L. Rural land property right system of China: Defects and solutions. Can. Soc. Sci. 2014, 10, 75-83.

20. Labbé, D. Critical reflections on land appropriation and alternative urbanization trajectories in periurban Vietnam. Cities 2016, 53, 150-155. [CrossRef]

21. Yeh, A.G.O. Dual land market and internal spatial structure of Chinese cities'. In Restructuring the Chinese Cities: Changing Society, Economy and Space; Routledge: London, UK, 2005.

22. Nguyen, V.S. Land Use Policy Reform in Vietnam-From Theory to Practice; The National Political Publishing House: Hanoi, Vietnam, 2010.

23. World Bank. East Asia Decentralises: Making Local Government Work; World Bank: Washington, DC, USA, 2005.

24. Zhang, J.X.; Yin, J.; Luo, X.L. Research of urban spatial development under the circumstances of local government's entrepreneuralization. Hum. Geogr. 2006, 4, 1003-2398. (In Chinese)

25. Vu, T.T.A. Decentralisation in Vietnam from Institutional Perpspective. Available online: http:/ / www.fetp. edu.vn (accessed on 31 December 2012). 
26. Qian, J.; Peng, Y.F.; Cheng, L.; Wu, C.; Du, Q.Y. Urban land expansion and sustainable land use policy in Shenzhen: A case study of China's rapid urbanization. Sustainability 2016, 8, 16. [CrossRef]

27. Embassy of Denmark; World Bank; Embassy of Sweden. Recognizing and Reducing Corruption Risks in Land Management in Vietnam; The National Political Publishing House: Hanoi, Vietnam, 2011.

28. Shi, K.; Chen, Y.; Yu, B.; Xu, T.; Li, L.; Huang, C.; Liu, R.; Chen, Z.; Wu, J. Urban expansion and agricultural land loss in China: A multiscale perspective. Sustainability 2016, 8, 790. [CrossRef]

29. Vietnam News. Farmers Question Ministry on Forced Land Acquisition. Available online: http:// vietnamnews.vn/society/229164/.html (accessed on 23 August 2012).

30. Michael Tatarski. A tale of two plans: Thu Thiem, Phu My Hung and future Saigon. Saigoneer. Available online: http:/ / saigoneer.com/saigon-development/11190 (accessed on 5 January 2018).

31. Han, S.S.; Vu, K.T. Land acquisition in transitional Hanoi, Vietnam. Urban Stud. 2008, 45, 1097-1117.

32. Truong, T.T.; Perera, R. Consequences of the two-price system for land in the land and housing market in Ho Chi Minh City, Vietnam. Habitat Int. 2011, 35, 30-39.

33. Nguyen, T.H.T.; Tran, V.T.; Bui, Q.T.; Man, Q.H.; Walter, T.d.V. Socio-economic effects of agricultural land conversion for urban development: Case study of Hanoi, Vietnam. Land Use Policy 2016, 54, 583-592. [CrossRef]

34. Nguyen, V.S. Industrialization and Urbanisation in Vietnam: How Appropriation of Agricultural Land Use Rights Transformed Farmer's Livelihoods in a Peri-Urban Hanoi Village. Final Report of an EADN Individual Research Grant Project. Available online: https: / / www.google.com/url?sa=t\&rct=j\&q=\&esrc=s\&source= web\&cd=1\&ved=0ahUKEwjkoZndlMDaAhWFk5QKHWWAAxEQFgglMAA\&url=http\%3A\%2F\%

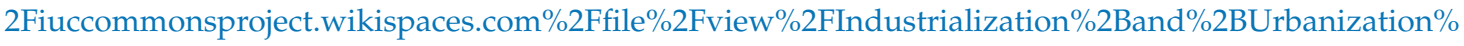
2Bin\%2BVietnam.pdf\&usg=AOvVaw2Uz-cyPKbsr2WoubIMjkEL (accessed on 16 April 2018).

35. He, S.; Liu, Y.; Webster, C.; Wu, F. Property rights redistribution, entitlement failure and the impoverishment of landless farmers in China. Urban Stud. 2009, 46, 1925-1949.

36. Wu, F. The game of landed-property production and capital circulation in China's transitional economy, with reference to Shanghai. Environ. Plan A 1999, 31, 1757-1771. [CrossRef]

37. Wu, F. The (post-) socialist entrepreneurial city as a state project: Shanghai's reglobalisation in question. Urban Stud. 2003, 40, 440-451. [CrossRef]

38. Tran, A.T. Local administration: The case of Ho Chi Minh City budget governance. In Proceedings of the Conference Les Villes Émergentes en Asie du Sud-Est; Ambassade de France au Laos: Vientiane, Laos, 2013; pp. $26-28$.

39. Kim, A.M. Talking back: The role of narrative in Vietnam's recent land compensation changes. Urban Stud. 2011, 48, 493-508. [CrossRef]

40. Cang, J.M.; Wang, W.M.; Li, B.J. Analysis on the evolution of basic farmland protection policy in China under political economy perspective. Reform Econ. Syst. 2006, 6, 84-88.

41. Lichtenberg, E.; Ding, C. Assessing farmland protection policy in China. Land Use Policy 2008, 25, 59-68. [CrossRef]

(C) 2018 by the authors. Licensee MDPI, Basel, Switzerland. This article is an open access article distributed under the terms and conditions of the Creative Commons Attribution (CC BY) license (http:// creativecommons.org/licenses/by/4.0/). 